\title{
Impact of World Bank Assisted Technical Education Project-III on Meghalaya, Mizoram and Tripura States of India
}

\author{
Thanikachalam Vedhathiri, \\ vthani2025@gmail.com \\ Former Professor and HOD, Center for International Affairs, \\ Thegarajan Ramadass \\ rtrajan59@gmail.com \\ Former Professor and HOD, Educational Media Center, \\ National Institute of Technical Teachers Training and Research, \\ Chennai-600113, India,
}

\begin{abstract}
The North-Eastern States lagged far behind other states of India due to severe shortage of human capital in engineering and technology. The economic growth of the region lagged far behind rest of the country. Government India implemented World Bank Assisted Project III from 2001 to 2007 in the North Eastern states. The impact study conducted as a sponsored research on three states viz, Meghalaya, Mizoram and Tripura indicate that the states need more polytechnics and engineering colleges to support faster industrialization due to "Look East Policy" of the Government of India. The isolation of states has come to an end. The youth can migrate to other industrialized states in other regions. The resources developed by the project helped many states to establish engineering degree programs in the same campus and the return on the investment increased and the existing employees have also been trained through continuing education in these polytechnics. The crime rate also reduced. The people of the region have been integrated with the rest of India. The region is capable of supporting new industries due to availability of industry ready technicians and engineers. The project has been classified as satisfactory by World Bank.
\end{abstract}

Keywords: Impact Study, World Bank Assisted Tech Ed III, Growth of Technician Education in North Eastern States of India,

\section{Introduction}

North Eastern states are having more fertile soil, water resources, forest and mineral wealth but lag behind industrialization. They need more trained human resources for establishing industries using the abundant natural resources like coal, timber, crude oils, fruits and vegetables. Arunachal Pradesh did not have any technical institute. Meghalaya, Mizoram and Tripura had one polytechnic only. The women could not get needed technician education in these states. In 2001 these states have been included in the third technical education project assisted by World Bank which was completed in 2007. Mizoram, and Tripura got one women polytechnic each and Meghalaya got two coeducational polytechnics in Tura and Jowai. The existing polytechnics in all the three states were modernized. The World Bank commissioned the Nodal Officer of NITTTR Chennai to conduct an impact study due the project.

\section{Literature Survey}

After completion of development projects, the International Development Agencies like Asian Development Bank, World Bank etc. are focusing the evaluation on the following aspects (Bamberger et al. 2010, Behrman, 2001, Boardman, et al. 2001, Imas, Linda and Ray, 2009, Rao and Michael, 2003):

- Innovation

- Replicability

- Effectiveness of the program in the particular context

- Influencing the policy makers in taking key decisions

- Strategical relevance

\section{Cost-Benefit Analysis}

Cost -benefit analysis estimates the total expected benefits of a development project, compared to its total expected costs. It seeks to quantify all of the costs and benefits of a project in monetary terms and assesses whether benefits outweigh costs.

\section{Cost -Effective Analysis}

Cost-effective analysis compares the relative performance of two or more alternative projects in reaching common outcome.

\section{Impact Evaluation}

Impact evaluation estimates the benefit and effective side, and cost analysis provides the cost information. In an ideal world, cost-benefit analysis based on impact evaluation evidence would exist not only for a particular project, but also for a series of projects or project alternatives, so that policy makers like secretary of state department technical education, could assess which 
project or alternative is most cost-effective in reaching a particular goal.

Planning Development Projects in Technician Education

Most of developing countries plan prepare detailed project proposal for getting financial assistance from various international development agencies like Asian Development Bank, and World Bank. The goals of the project center around three focused areas like capacity development, quality improvement, and efficiency improvement. Under capacity development new educational institutions, workshops, laboratories, buildings, quarters, hostels, field labs etc. are planned.

Under quality improvement, new curricula, faculty development, continuing education, instructional materials development, industrial training, examination reforms etc. are undertaken.

Under efficiency improvement more focus would be taken on refining educational administration, placing students, conduct of tracer studies, utilization of the project resources, equipment, undertaking sponsored projects, extending testing facilities to the government, industries and society.

The project authorities commission professional development institutes like National Institutes of Technical Teachers Training and Research for academic consultancy, RITES for civil construction, Educational Consultants of India for procuring the equipment.

The Academic Consultant plans faculty development based on the need's analyses, curricula based on the needs of the employers and prepares equipment specification for procuring through Educational Consultants of India. In addition, it monitors the project implementation against the planned development.

Further it undertakes needed research works like continuous improvement in teaching learning, equipment and space utilization, planning continuing education centers for developing working professions by the project institutes. Once in six months the Joint Review Mission is convened to review the progress on project implementation. The bottlenecks are resolved in consultation with the government.

There many failures in some projects for following reasons:

- Shortage of land in appropriate location

- Improper design and execution of buildings

- Improper programs and courses planned

- Too many controls in allocating the land

- Improper leadership and administrators

- Corruption in many project activities

- Shortage of qualified and competent faculty
- Trained faculty leaving the project institutes after the expiry of their deputation for their parent organizations

- Not having funds for maintenance of the equipment

- Not able to recruit qualified faculty members

- Not able to generate internal revenue through testing and consultancy services

- Fail to establish skill development centers and community development departments as planned

- Not conducting training courses for the employees of MSMEs

- Not having mentor institutes for the project institutes

- Not getting the feedback from the stake holders for identifying the obstacles and pitfalls

- Not taking timely measures to resolve the conflicts and bottle necks

\section{Need for Independent Evaluators to Study the Impact of the Project on the Region}

Most of the times, the project authorities commission professional institutes to conduct impact studies to get unbiased reports who were not the planners for the projects. The areas of focus for impact study are:

- Choosing an impact evaluation model for the completed project

- Following ethics

- Setting up a qualified and competent team to investigate and get the feedback from the stakeholders

- Developing questionnaires based on the approved project implementation plan

- Planning institutional visits, and getting the feedback from the stakeholders

- Reviewing performance records

- Reviewing the course outcomes from the tracer study reports

- Consulting government officials, employers, alumni, parents and society at large

- Conducting seminars to get the opinions from the stakeholders and society at large

- Critically reviewing the return from the project institutions like employment of the graduates, services rendered to MSMEs, government departments, and to the society at large.

- Authentically preparing the gains and innovations.

- Proving unbiased adjudication on the total impact on the region by the project institutes 
Status of the polytechnics before the Project

Table-1

\begin{tabular}{|l|l|l|l|}
\hline State & $\begin{array}{l}\text { Men's } \\
\text { Polytechnic }\end{array}$ & $\begin{array}{l}\text { Women's } \\
\text { /Coeducational } \\
\text { Polytechnic }\end{array}$ & $\begin{array}{l}\text { Testing } \\
\text { centers }\end{array}$ \\
\hline Meghalaya & $\begin{array}{l}\text { One at at } \\
\text { Shillong }\end{array}$ & Nil & Nil \\
\hline Mizoram & One & Nil & Nil \\
\hline Tripura & One & Nil & Nil \\
\hline
\end{tabular}

\section{Initiatives of Government of India}

The north eastern states need more trained technicians and engineers to carry out the development plans. The states started growing due to new industrial policy of Government of India. Special Economic Zones are being planned under 'Look East Policy'. New manufacturing industries with foreign direct investments (FDI) are planned in many states. This demands well trained technicians and engineers in these states.

\section{Technician Needs of the States}

- Technicians with knowledge of computer applications, digital technology and medical electronics

- Technicians with electrical engineering for working in power generation, distribution and maintenance

- Electronics technicians work in telecommunication departments

- Technicians to construct civil structures, roads, highways and water supply \& waste water treatment plants

- Technicians to work as architectural assistants

- Technicians to maintain automobiles like cars, two wheelers and three wheelers

- Technicians to work in furniture making and handicrafts production

- Technicians in costume design, garment technology, and fashion technology

- Technicians work in beauty parlors

- Technicians in food technology based MSMEs

- Technicians in biochemistry to work in hospitals and medical labs

- Technicians to work in manufacturing herbal products

\section{Objectives of the Impact Study}

The following are the objectives of this study:

- Assess the employment potential of the graduates of these project polytechnics.
- Study the envisaged impact of the technicians on the North Eastern States.

- Identify the satisfaction of the students, employers and people on the starting of the polytechnics.

- Assess the possible development of the economy of the state's due to technical manpower.

\section{Motivation}

The hill states need trained engineering graduates for starting MSMEs, using natural materials, forest resources and modernizing the micro enterprises. Now it is essential to study the cultural impact of the newly established polytechnics and the changes introduced through various diploma programs on the perception of the local population.

\section{Research Questions}

Whether strategic planning has been prepared and implemented by the project polytechnics?

Whether the leaders and administrators have been trained to continuously transform the institute programs to meet the fast- changing economy?

Whether the institutions constantly interact with the stakeholders and offer needed technical assistance?

What is the cultural impact on the states?

Whether the project assisted to increase in supply of the youth in the region and beyond?

Is it possible for the graduates to start needed enterprises due to training the students of these three states?

Whether women students prefer technician education programs?

Is there any abnormal dropout of the students after admission?

Are women students ready to move to other states for jobs?

What are the bottlenecks in expanding the outreach programs to other districts to train the in-service technicians of government departments and MSMEs?

Are faculty have been trained to conduct needs analysis and prepare relevant outcome- based training programs for the working professionals?

What are measurable benefits to the local MSMEs?

Are there any further need for establishing more polytechnics in various regions of the state? 
Are there visible needs for engineering colleges to meet the needed engineers under Look East Policy?

Can the project polytechnics be utilized to offer degree programs in another shift?

Can they utilize the resources and trained faculty to improve the skills and competencies of the local employees and technicians of government engineering departments?

Whether the current programs can be sustained by the state governments? Do they need additional funds from the central government?

What are the views of parents?

What are the views of alumni on the relevance of the courses and training offered?

Is it possible to develop Special Economic Zones (SEZ) in these states under 'Look East Policy'?

Whether the faculty members and the administrators have been trained to continuously improve the curricula and their implementation?

What is return on investments on the project institutes?

\section{Research Methodology}

Naturalistic evaluation method has been used for this impact study. The following are components of the impact assessment:

1. Preparing the questionnaire for getting the feedback from stakeholders

2. Visiting the project polytechnics for observing the use of resources. All the seven project polytechnics were visited by the researchers and detailed discussions were held with the principals, faculty members and the officials of State Project Implementation Unit (SPIU).

3. Getting the feedback on the questionnaires and opinions from the stakeholders (faculty members, students of the project polytechnics and local entrepreneurs/ alumni). The faculty of all seven project polytechnics provided their feedback besides completing the questionnaires.

4. Conducting local seminars with the participation of community members, alumni, parents, entrepreneurs, employers, government officials and public at large. Three seminars for Meghalaya, two for Mizoram, and two for Tripura have been conducted in cooperation with the Principals of the project polytechnics. In each seminar around 50 people attended and provided their unbiased feedbacks.

5. Analyzing their feedbacks, preparing reports and discussing the outcomes with the officials of State Project Implementation Units (SPIU), and

6. Finally presenting the impact study before the Joint Review Committee of World Bank Officials and the State Officials.

\section{Faculty Development Process adopted to Create Outstanding Impacts on the States}

- Strategic planning of educational programs, services to the society

- Leadership development

- Continuous process of developing needed courses based on the emerging technology

- Creating a 'learning organization'

- Using 'normative process of educational changes and transformations' in the project polytechnics

- Establishing Continuing Education Centers and offering training and development programs for the employees who are from government departments and MSMEs

- Offering needed programs in skill development for out of school youth in the states

- Offering courses on the use of Internet and use of emails for business and personal use

\section{Contribution of the Project to the States}

\section{Meghalaya}

In Meghalaya two polytechnics were introduced two new polytechnics in Tura and Jowai. Tura Polytechnic offers diploma programs in computer science, medical electronics and food processing. The computer science graduates are absorbed in various government offices and local micro enterprises and many graduates got jobs in other states like West Bengal. The medical electronics students got jobs in local hospitals and other states. The food technology graduates joined jobs in local as well as in bigger hotels in other states. The modern equipment of Food Technology Department was also used by the home science department of local colleges. Jowai Polytechnic offers diplomas in Costume Design and Garment Technology, Automobile Engineering, and Architectural Assistanceship. The graduates are very absorbed. Shillong Polytech offers Diplomas in Civil Engineering, Mechanical Engineering, Electrical Engineering, Electronics and Communication Engineering and Computer Science. The graduates are absorbed very well.

\section{Mizoram}


The existing polytechnic in Lungile was modernized with needed infrastructure. A new women's polytechnic has been established in Aizawl. New programs were introduced in both polytechnics. Students got jobs in NCR Delhi, West Bengal, Maharashtra and Jaipur. More women joined the technician programs. The working engineering personnel were trained to improve their skills in computer- based design and drawing.

\section{Tripura}

One women polytechnic was started near Narasingar. This offers Diplomas in Computer Science and Technology, Information Technology, Electronics and Telecommunication, Medical Lab Technology and Fashion Technology. In the existing polytechnic in Narasinghar offers diplomas in Computer Science and Technology, Automobile Engineering, Interior Decoration, Handicrafts and Furniture Design and Modern Office Management. All the programs are very relevant for the students. The students of Costume Design and fashion Technology conducted fashion shows which are published in the newspapers. Tripura added three more polytechnics recently. They polytechnic in Narasinghgar is offering engineering degree programs in the afternoon sessions using the resources. This provides needed human resources for industry development as per Look East Policy.

\section{Implications}

The new polytechnics have provided more opportunities to the local students to undergo needed diploma programs within the states instead of migrating to other states. The women students got sufficient opportunities to enroll in the desired branches within the state and get gainful employments in other states also. This brought more integration of the states with rest of India. Many have become entrepreneurs in automobile repairing, costume design and garment making, fashion design, and building construction. The Government's vison of starting many special economic zones in this region and connecting with Myanmar and Thailand is possible due to the availability of trained manpower. The continuing education programs brought satisfaction to the local employees and women. The strength of the trained graduates in computer science and information technology assisted in the e-commerce and e-governance. The use of Internet has increased to a greater extent. The polytechnic graduates started pursuing degree programs through lateral entry. The North Eastern Region is poised for greater economic growth.

\section{Significant Outcomes of the Project}

- Enrollment of women students in engineering programs is far above planned number in the project. This has attracted the World Bank to study and replicate in other projects.

- Two states (Tripura and Meghalaya) have further utilized the project polytechnics for offering engineering degree programs through a shift system.

- The graduates, parents and public at large welcomed the project outcomes.

- Local MSMEs have been benefitted very much due to the market ready technicians and other technical services offered by them.

- There is a significant motivation in the school students to pursue the technician programs and all the seats were filled through proper recruitment process.

- This has contributed to poverty alleviation.

- The hill tribes of the project states were very happy on the Continuing Education Programs and Training in Internet application.

- The project created a total transformation in their educational planning and satisfied on the development brought in to the human resources.

- The State Officials needed more state specific courses to get more return on the investments made.

- The methodology followed to plan significant programs, involvement of the State Directorate, training offered to the faculty members are very much appreciated. Further this gave rise to more outreach programs.

- The project institutes created significant cultural impact and the state population welcomed the further institutions in science, engineering and technology so that the students can become needed human capital in the North Eastern states.

- The need to go to other states for technical education was minimized through this project.

- The diplomads have continued to acquire degrees through lateral entry.

- Around $1.3 \%$ of the diplomads started focusing on entrepreneurship.

- A few women technicians established garment manufacturing in Aizawl (Mizoram).

- One-woman technician in mechanical engineering started an automobile serving and repair unit in Shillong (Meghalaya).

- The technician students focused on problem solving abilities and ready to get employment in the western India. 
- These polytechnics brought peace engineering education in these turbulent states.

- The Officials of Directorate of Technical Education became more confident in state specific programs and courses for the working professionals.

- The project institutes were very much liked by the state population and felt more confidence in the economic growth.

\section{Results and Discussion}

The Government of India accepted to fund for starting NITs in all these states and also utilize the resources of the project polytechnics to permit degree programs in Tripura, Andaman and Nicobar Islands, Arunachala Pradesh, and Meghalaya.

The project brought success in planning appropriate technician programs which are needed for the development of North Eastern States.

The outcome oriented programs assisted the diplomads in getting jobs even in Maharashtra State.

This project has been rated as "satisfactory" by World Bank.

It is truly a peace engineering project and created needed peace in many troubled states.

\section{Conclusions}

The project polytechnics have produced needed human resources for planned e commerce in the states.

The return on investment is quite large with respect to employment of diplomads (polytechnic graduates), creating new MSMEs using local resources.

The states do not require technicians from outside the states. The women students of Beautician programs were employed in various five- star hotels in the western states like Rajasthan.

Most of the diplomads got jobs not only in the states, but also, in other western states like Maharashtra due to mentoring of the students and industrial training.

Most of technicians were employed in MSMEs in the state. Women technicians started getting jobs in other regions also.

Later the Government of India established National Institutes of Technology in all North Eastern states. The TEQIP III project was extended to these NITs.
The Project has been termed as "satisfactory" by World Bank and brought improvements in the human capital. The inclusion more women has out passed the planning.

\section{Acknowledgement}

The assistance provided by SPIUs, Project Polytechnics, NPIU and other stake holders is gratefully acknowledged.

\section{References}

Bamberger, Michael, Vijayendra Rao, and Michael Woolcock. (2010). Using Mixed Methods in Monitoring and Evaluation: Experiences from International Development. Policy Research Working Paper 5245, Washington, DC: World Bank.

Behrman, Jere R., and John Hoddinott. (2001). An Evaluation of the Impact of PROGRESA on Pre-school Child Height. FCND Briefs 104, Washington, DC: International Food Research Institute.

Boardman, Anthony, Aidan Vining, David Greenberg, and David Weimer. (2001). Cost-Benefit Analysis: Concepts and Practice. New Jersey: Prentice Hall

Detailed Project Proposals for Technician Education III. (2000). Meghalaya, Mizoram and Tripura.

Imas, Linda G. M., and Ray. C. Rist. (2009). The Road to Results: Designing and Conducting Effective Development Evaluations. Washington, DC: World Bank

State Project Implementation Units (2007). Project Completion Reports of Meghalaya, Mizoram, and Tripura. Noida: National Project Implementation Unit

Thanikachalam. V and Theagarajan. R. (2007). Reports on the Impact Study on Meghalaya, Mizoram and Tripura, Noida: National Project Implementation Unit.

Thanikachalam. V. (2007). Sustenance of Project Innovation in the North Eastern States. Port Blair: Joint Review Commission of the World Bank.

Vijayendra Rao, and Michael Woolcock. (2003). Integrating Quantitative Approaches in Program Evaluation- In The Impact of Economic Policies on Poverty and Income Distribution: Evaluation Techniques and Tools, ed. F. J. Bourguignon, and L. Pereira da Silva-165-90. New York: Oxford University Press 